\title{
Pengaruh BPA (Bisphenol A) terhadap Kadar Insulin dalam Serum Darah Tikus Wistar Jantan
}

\author{
(Effect of BPA (Bisphenol A) on Blood Serum Insulin Levels in Adult Male Wistar Ras)
}

Fitria Nurhabiba Agustine', Swasthi Prasetyarini², Zahreni Hamzah ${ }^{3}$

1 Fakultas Kedokteran Gigi Universitas Jember

2 Bagian IImu Kedokteran Gigi Dasar, Fakultas Kedokteran Gigi, Universitas Jember

3 Bagian Biomedik, Fakultas Kedokteran Gigi, Universitas Jember

\begin{abstract}
Abstrak
BPA merupakan bahan sintetis yang banyak digunakan pada bahan dasar pembuatan PVC. PVC dibutuhkan dalam produksi peralatan rumah tangga, wadah makanan, botol air mineral, botol susu dan sealant gigi. BPA dikenal sebagai salah satu EDC yang memiliki efek meningkatkan kadar insulin dalam darah. Selanjutnya BPA bisa mengarah ke DMT2. Tujuannya adalah untuk mengetahui pengaruh BPA terhadap kadar insulin darah tikus wistar jantan dewasa. Sebanyak 18 ekor tikus wistar jantan dibagi menjadi 3 kelompok. Larutan BPA dibuat dengan melarutkan 20 mg / kgBB kristal BPA ke dalam minyak jagung. Kelompok 1 (K1) tidak diberikan perlakuan apapun dan dibedah pada hari ke-0. Kelompok 2 (K2) diberi perlakuan akuades secara oral selama 28 hari dan dibedah pada hari ke-29. Kelompok 3 (P) diberi perlakuan larutan BPA secara oral selama 28 hari dan dibedah pada hari ke29. Pengobatan diberikan satu kali sehari pada pukul 09.00. Darah dikumpulkan setelah 12 jam berpuasa. Pengambilan darah dilakukan dengan tikus dianastetik terlebih dahulu dengan eter $10 \%$ melalui inhalasi kemudian dibedah tikus sampai jantung terbuka. Darah diambil dari jantung sebanyak $3 \mathrm{ml}$ dan disentrifugasi untuk diambil serumnya. Pemeriksaan insulin dilakukan dengan ELISA pada serum yang telah terkumpul. Data dianalisis dengan uji One Way Anova dan Post hoc Test LSD. BPA dosis $20 \mathrm{mg} / \mathrm{kgBB}$ meningkatkan kadar insulin serum darah tikus wistar jantan dewasa sebesar 1,38 mlU / L.
\end{abstract}

Kata kunci: BPA, insulin, serum darah.

\section{Abstract}

BPA is a synthetic material that widely used in basic material of PVC making. PVC is needed in production of household appliances, food container, mineral water bottles, feeding bottles and dental sealant. BPA is known as one of EDCs which have an effect to increase insulin levels on blood. Furthermore, BPA could lead to DMT2. The objective was to determine the effect of BPA on blood insulin levels in adult male wistar rats. 18 male wistar rats were divided into 3 groups. BPA solution was made by dissolve 20 mg/kgBB crystal BPA into corn oil. Group 1 (K1) not given any treatment and dissected in day-0. Group 2 (K2) given aquadest treatment orally for 28 days and dissected in day-29. Group 3 (P) given BPA solution treatment orally for 28 days and dissected in day-29. The treatment given once a day on $09.00 \mathrm{AM}$. The blood collected after 12 hours fasting. Blood collecting procedure done with the rats were anasthetized first with eter $10 \%$ through inhalation and then dissect the rats until the heart is exposed. Blood was collected from the heart for $3 \mathrm{ml}$ and were sentrifugated to get the serum. Insulin examination done by ELISA on serum that has been collected. Data were analyzed by One Way Anova test and Post hoc Test LSD. BPA with 20 $\mathrm{mg} / \mathrm{kgBB}$ dose increasing blood serum insulin levels on adult male wistar rats by $1,38 \mathrm{mIU} / \mathrm{L}$.

Keywords: Insulin, BPA, Blood serum.

Korespondensi (Correspondence) : Fitria Nurhabiba Agustine, Universitas Jember, Jl. Kalimantan No 37, Jember, email: ftian.hb@gmail.com

Bisphenol A atau yang biasa disebut dengan BPA adalah sebuah senyawa sintetis yang banyak digunakan dalam bentuk monomer pada produksi plastik polikarbonat (PC) dan resin epoksi.' Polikarbonat (PC) banyak digunakan sebagai bahan wadah makanan dan minuman, seperti botol susu bayi, perlatan makan, kotak makanan, botol air minum, botol susu dan minuman ringan, alat pengolah makanan dan pipa air. Sedangkan, epoksi resin digunakan sebagai bahan pelapis pengaman pada berbagai makanan dan minuman kaleng dan sebagai pelapis pada tutup logam pada toples kaca dan botol, termasuk wadah yang digunakan sebagai tempat susu formula bayi. Pada kedokteran gigi PC juga digunakan sebagai bahan dasar salah satu dental sealant, yaitu komposit dan bahan dasar dari resin akrilik, yaitu bahan utama dari pembuatan basis gigi tiruan.2

BPA dapat lepas dari rantai polikarbonat menjadi cairan dan berkontaminasi dengan makanan atau minuman melalui proses difusi atau hidrolisis polimer. Proses difusi residu BPA kedalam makanan biasa terjadi pada makanan kering yang diproduksi oleh pabrik. Sedangkan pada makanan basah yang mengandung banyak cairan, proses yang biasa terjadi adalah proses hidrolisis. ${ }^{3}$

Insulin merupakan suatu hormon peptida yang sintesis dan di sekresi oleh sel $\beta$ kelenjar pankreas. Insulin terdiri dari dua rantai polipeptida a dan $\beta$ yang dibentuk dari 51 asam amino. Rantai a mengandung 21 asam amino dan rantai $\beta$ mengandung 30 residu asam amino. Insulin merupakan hormon yang memiliki peran penting pada regulasi kadar glukosa dalam tubuh. 4 
Insulin sangat berpengaruh terhadap metabolisme karbohidrat, sehingga banyak dihubungkan dengan gula darah. Bila terdapat sejumlah besar makanan tinggi gula, terutama dalam bentuk karbohidrat, insulin akan disekresikan dalam jumlah besar. Insulin memainkan perananan penting dalam penyimpanan kelebihan energi. Insulin berfungsi untuk merubah kelebihan glukosa yang dibentuk dari karbohidrat diet menjadi glikogen dan menyimpannya dalam hati dan otot sebagai energi cadangan. ${ }^{5}$

BPA memiliki pengaruh terhadap terhadap peningkatan penyakit metabolik Diabetes Mellitus (DM) terutama Diabetes Mellitus Tipe 2 (DMT2). Paparan BPA dalam kadar tertentu memiliki pengaruh pada kerusakan sel $\beta$ pankreas yang memicu terjadinya DM. BPA memiliki sifat estrogenic, yaitu menyerupai hormone estrogen. BPA dapat mengikat dan mengaktivasi reseptor estrogen secara spesifik. ${ }^{6}$ Estradiol $\left(E_{2}\right)$ atau yang lebih dikenal dengan estrogen banyak diketahui berfungsi sebagai hormon seks, namun beberapa penelitian menyatakan $E_{2}$ memiliki peran lain pada sistem tubuh. Termasuk keseimbangan energi dan homeostasis glukosa. $\mathrm{E}_{2}$ memiliki peranan penting untuk mempertahankan normalitas sensitivitas insulin. Kadar $E_{2}$ yang berada di atas maupun di bawah batas fisiologis akan memicu resistensi insulin dan berlanjut pada DMT2.7

Estradiol ( $\left.E_{2}\right)$ ikut memegang peranan penting pada fisiologi dan kapasitas produksi insulin pada sel $\beta$ pankreas. $E_{2}$ memiliki dua isoform, ERa dan ER $\beta$ yang terdapat pada pankreas. Aktivasi ERa akan menyebabkan proliferasi sel $\beta$ dan aktivasi ERß akan meningkatkan sekresi insulin. BPA yang masuk ke dalam sistem tubuh, akan mempengaruhi kedua isoform ini. 8

$\begin{array}{ccc}\text { Paparan } & \begin{array}{c}\text { kronis } \\ \text { kronis }\end{array} & \text { menyebabkan } \\ \text { paparan } & \text { menyebabkan }\end{array}$
hiperinsulinemia, perburukan toleransi glukosa, dan berkurangnya sensitivitas insulin. Dalam hal ini, yang perlu diperhatikan meskipun sekresi insulin sel $\beta$ pankreas meningkat, gangguan kerja insulin justru terjadi. ${ }^{7}$ Hal ini terjadi karena beberapa mekanisme yang mendasari kerja BPA yang secara tidak langsung menyebabkan resistensi insulin. Makin tinggi kadar insulin yang diinduksi BPA dapat menghasilkan kompensasi berupa resistensi insulin. Secara keseluruhan, pengaruh paparan kronis BPA pada homeostasis glukosa menguatkan dugaan BPA adalah salah satu dari faktor diabetogenik yang menyebabkan terjadinya DMT2.

Berdasarkan latar belakang masalah yang telah dibahas, maka penulis bermaksud untuk melakukan penelitian eksperimental laboratoris untuk mengetahui pengaruh BPA terhadap kadar insulin dalam serum darah tikus wistar jantan.

\section{METODE PENELITIAN}

Jenis penelitian yang dilakukan adalah penelitian eksperimental laboratoris dalam bidang fisiologi dengan rancangan penelitian Randomized separate pretest-postest control group design. 9 Sampel yang digunakan dalam penelitian ini sebanyak 18 ekor tikus wistar jantan yang dibagi kedalam 3 kelompok, yaitu kelompok kontrol yang dibedah pada hari ke-0 (K1), kelompok kontrol yang diberi perlakukan berupa sondase aquadest selama 28 hari dan dibedah pada hari ke-29 (K2) dan kelompok perlakuan yang diberi sondase larutan BPA 20 $\mathrm{mg} / \mathrm{kgBB}$ selama 28 hari dan dibedah pada hari ke-29 (P). Pada penelitian ini tikus diadaptasi dengan lingkungan serta diberi makanan standar dan minuman secara ad libitum selama 7 hari.

Pembuatan sediaan BPA dilakukan dengan melarutkan $20 \mathrm{mg} / \mathrm{kgBB}$ kristal BPA dengan minyak jagung sesuai dengan konsentrasi yang diinginkan. Larutan BPA kemudian dimasukkan ke dalam botol dan disimpan pada suhu $40 \mathrm{C}$ sampai akan digunakan.

Pemberian perlakuan diberikan berdasarkan kelompok. K1 tidak diberi perlakuan, K2 diberi perlakuan berupa sondase aquadest selama 28 hari dan P diberi perlakuan berupa sondase larutan BPA selama 28 hari. Pemberian perlakuan dilakukan sekali sehari pada pukul 09.00.

Prosedur dekapitasi dibagi menjadi 2 waktu, yaitu pada hari ke-0 dan hari ke-29. Pada hari ke-0 atau setelah adaptasi hewan coba selama 7 minggu, tikus pada kelompok K1 dibedah setelah 12 jam dipuasakan. Sedangkan pada kelompok K2 dan $P$ dibedah pada hari ke-29 setelah sebelumnya dipuasakan selama 12 jam. Pembedahan dilakukan dengan anastesi menggunakan eter $10 \%$ secara inhalasi sebelumnya untuk diambil darahnya. Pengambilan darah dilakukan melalui jantung sebanyak $3 \mathrm{ml}$. Darah yang telah dikumpulkan kemudian dilakukan sentrufugasi dengan kecepatan 3000 rpm selama 7 menit kemudian serum dipisahkan dan disimpan pada suhu $-20^{\circ} \mathrm{C}$ sampai akan digunakan. Prosedur pemeriksaan insulin menggunakan ELISA kit dilakukan sesuai dengan manual book ELISA kit BT Lab.

Setelah data hasil penelitian diperoleh, data tersebut dianalisis secara statistik. Uji normalitas menggunakan Uji Shaphiro-wilk, selanjutnya dilakukan uji homogenitas menggunakan Levene's test dan dilanjutkan dengan uji One Way Anova untuk mengetahui ada atau tidaknya perbedaan yang signifikan antar kelompok, kemudian dilanjutkan dengan uji Post Hoc LSD (Least Significant Differences) untuk mengetahui pada kelompok mana terdapat perbedaan yang signifikan. 


\section{HASIL PENELITIAN}

Hasil rata-rata kadar insulin serum darah, glukosa darah dan berat badan tikus disajikan dalam tabel dan gambar dibawah (terlampir). Data hasil penelitian, selanjutnya dianalisis secara statistik untuk mengetahui apakah data pada masing - masing kelompok berdistribusi normal atau tidak. Uji normalitas yang digunakan adalah Uji Shaphiro-wilk, karena jumlah sampel kurang dari 50. Hasil uji Shaphiro-wilk diperoleh nilai signifikansi (p) $>0,05$, sehingga dapat disimpulkan bahwa data berdistribusi normal. Setelah itu, dilanjutkan dengan uji homogenitas menggunakan Levene's test. Hasil uji homogenitas dengan Levene's test menunjukkan nilai signifikansi $(p)>0,05$, yaitu 0,321 , sehingga dapat disimpulkan bahwa data homogen. Berdasarkan hasil uji Shaphirowilk dan uji Levene's test, diketahui bahwa data berdistribusi normal dan homogen, sehingga dapat dilanjutkan uji beda parametrik One Way Anova. Hasil uji beda One Way Anova menunjukkan nilai signifikansi (p) sebesar 0,000, yang berarti terdapat perbedaan yang bermakna, sehingga selanjutnya dilakukan uji Post hoc LSD (Least Significant Difference). Hasil uji Post hoc LSD menunjukkan terdapat perbedaan yang signifikan antara kelompok $\mathrm{K} 1$ dengan $\mathrm{P}$ dan K2 dengan P. Sedangkan pada kelompok K1 dengan $P$ perbedaan yang terjadi tidak signifikan.

Tabel 1. Kadar Insulin Serum Tikus Wistar Jantan (mlU/L)

\begin{tabular}{cc}
\hline Kelompok & Kadar Insulin Serum \\
\hline K1 & $0,35 \pm 0,38$ \\
K2 & $0,64 \pm 0,20$ \\
P & $2,0 \pm 0,57$ \\
\hline
\end{tabular}

Tabel 2. Kadar Glukosa Darah Tikus Wistar Jantan (mg/dl)

\begin{tabular}{ccc}
$\begin{array}{c}\text { Minggu } \\
\text { ke- }\end{array}$ & Kelompok & $\begin{array}{c}\text { Kadar Glukosa } \\
\text { Darah }\end{array}$ \\
\hline 1 & $\mathrm{~K} 2$ & $98,00 \pm 11,98$ \\
& $\mathrm{P}$ & $93,17 \pm 7,44$ \\
\hline 2 & $\mathrm{~K} 2$ & $102,83 \pm 9,97$ \\
& $\mathrm{P}$ & $115,67 \pm 20,25$ \\
\hline 3 & $\mathrm{~K} 2$ & $98,67 \pm 13,56$ \\
& $\mathrm{P}$ & $121,17 \pm 25,69$ \\
\hline 4 & $\mathrm{~K} 2$ & $97,67 \pm 4,32$ \\
& $\mathrm{P}$ & $122,67 \pm 19,03$ \\
\hline
\end{tabular}

\section{PEMBAHASAN}

Berdasarkan hasil uji statistik, masingmasing kelompok memiliki perbedaan yang berarti. Pada K1 dan K2 didapatkan signifikansi sebesar 0,25 . Hal ini berarti bahwa pada kelompok $\mathrm{K} 1$ dan K2 memiliki perbedaan yang tidak signifikan. Pada kelompok $\mathrm{K} 1$ dan $\mathrm{P}$ didapatkan signifikansi sebesar 0,00, yang berarti terdapat perbedaan yang signifikan. Hal ini juga terjadi pada K2 dan $\mathrm{P}$ dengan angka signifikansi sebesar 0,00 .

Tabel 3. Berat Badan Tikus Wistar Jantan

\begin{tabular}{ccl}
\hline Hari ke- & Kelompok & Berat Badan \\
\hline \multirow{2}{*}{0} & K1 & $197.86 \pm 8,07$ \\
& K2 & $250.25 \pm 14,51$ \\
& $P$ & $241.25 \pm 7,61$ \\
\hline \multirow{2}{*}{7} & K2 & $253.57 \pm 15,68$ \\
& $P$ & $244 \pm 6,02$ \\
\hline \multirow{2}{*}{14} & K2 & $264.43 \pm 16,38$ \\
& $P$ & $251.14 \pm 9,35$ \\
\hline \multirow{2}{*}{21} & K2 & $270.43 \pm 14,35$ \\
& $P$ & $256.43 \pm 8,18$ \\
\hline \multirow{2}{*}{28} & K2 & $275.71 \pm 13,73$ \\
& $P$ & $265.86 \pm 10,33$ \\
\hline
\end{tabular}

Kadar insulin terendah didapatkan pada kelompok K1, yaitu kelompok kontrol yang dibedah pada hari ke-0, sedangkan pada K2 terjadi kenaikan kadar insulin sebesar 0,25 $\mathrm{mlU} / \mathrm{L}$. Kenaikan ini terjadi kemungkinan disebabkan oleh stress yang didapat oleh tikus saat dilakukan sondase dengan aquades secara kronik selama 28 hari. Hasil ini sesuai dengan penelitian Yan, et. A/10 yang menyatakan bahwa stress fisiologis yang terjadi secara kronis berhubungan langsung dengan IR (Insulin Receptors). Stress yang terjadi berakibat pada menurunnya sensitivitas IR dan terjadi Insulin Resistance sehingga insulin yang telah diproduksi tidak dapat digunakan dan terjadi penumpukan glukosa pada pembuluh darah. Sebagai akibat dari terjadinya Insulin Resistance dan penumpukan glukosa, pankreas akan meningkatkan sekresi insulin sehingga menyebebabkan kenaikan konsentrasi insulin di dalam plasma darah. Usia juga mempengaruhi jumlah insulin pada darah oleh karena penambahan sel $\beta$ yang terjadi di pankreas. Semakin tua usia maka semakin jumlah sel pada tubuh akan semakin banyak. ${ }^{11}$

Hasil rata-rata kadar insulin dalam serum darah pada kelompok $P$ terjadi peningkatan yang signifikan dibandingkan dengan kelompok K1 dan $\mathrm{K} 2$. Hal ini terjadi sesuai dengan pendapat Alonso-Magdalena et al serta Perdana dan Jacobus.7.12 yang menyatakan bahwa BPA menyebabkan kenaikan kadar insulin plasma. Kenaikan kadar insulin plasma kemungkinan disebabkan oleh BPA yang berperan sebagai EDCs dan bersifat estrogenik dan dapat mengikat dan mengaktivasi reseptor estrogen secara spesifik. ${ }^{6}$ Estrogen atau estradiol $\left(\mathrm{E}_{2}\right)$ tidak hanya berfungsi terbatas sebagai hormon reproduksi pada wanita. Estradiol berfungsi hampir diseluruh tubuh manusia dan terlibat pada proses fisiologi dan patologi baik pada wanita maupun pria. $E_{2}$ memiliki peranan penting untuk mempertahankan normalitas sensitivitas insulin. $E_{2}$ baik secara langsung maupun tidak langsung 
mempengaruhi ikatan insulin pada IR dan atau aktivasi IR. Kadar $E_{2}$ yang berada di atas batas normal atau disebut dengan hiperestrogenemik menyebabkan penurunan signifikansi aktivitas insulin dan IR sehingga menyebabkan insulin resistence. ${ }^{13}$

$\mathrm{E}_{2}$ memiliki 3 isoform dalam tubuh manusia, yaitu ERs yang terletak di sitoplasma dan terdiri dari ERa dan ER $\beta$ dan ERRY yang terletak pada membran sel. Aktivasi ERa akan menyebabkan proliferasi sel $\beta$ dan aktivasi ER $\beta$ akan meningkatkan sekresi insulin. ${ }^{8}$ Selain fungsi yang disebutkan diatas, ERa dan ER $\beta$ juga berfungsi dalam pengaturan transport glukosa dan insulin melalui GLUT4 (Glucose transporter type 4). ERa dan ERß memodulasi ekspresi GLUT4 sehingga menjadi salah satu faktor dalam pengambilan glukosa kedalam sel. ERa dan ERß memiliki peran yang berkebalikan pada ekspresi GLUT4. Aktivasi ERa membantu ikatan IR dan menstimulasi ekspresi GLUT4. Hal ini menyebabkan peningkatan ekspresi GLUT4 sehingga penggunaan glukosa oleh jaringan akan semakin baik. Sedangkan pada ER $\beta$ akan terjadi hal yang sebaliknya. Aktivasi ERß akan menekan ekspresi GLUT4. ${ }^{14}$

Aktivasi ERß banyak dihubungkan dengan efek diabetogenik. Hal ini diakibatkan karena aktivasi ER $\beta$, ekspresi GLUT4 akan mengalami penurunan sehingga insulin akan sulit masuk ke dalam sel dan glukosa tidak dapat digunakan dengan maksimal. Glukosa yang tidak dapat masuk ke dalam sel untuk diubah menjadi ATP akan menumpuk di pembuluh darah yang selanjutnya pada kejadian ini disebut dengan hiperglikemia. Akibat dari kondisi hiperglikemia ini, pankreas sebagai produsen insulin akan terstimulasi untuk memproduksi insulin lebih banyak untuk menekan jumlah glukosa yang melebihi batas normal pada pembuluh darah. Insulin yang banyak diproduksi ini selanjutnya juga akan menumpuk di dalam darah sebagai alat transportasi akibat dari turunnya ekspresi GLUT4 pada jaringan. Insulin yang menumpuk dalam darah ini selanjutnya disebut dengan hiperinsulimia.

BPA yang masuk ke dalam sistem tubuh, akan mempengaruhi kedua isoform $\mathrm{E}_{2}$ ini. $\mathrm{BPA}$ akan berikatan pada salah satu maupun kedua isoform tersebut oleh karena sifat estrogeniknya. Menurut penelitian yang dilakukan Matsushima, et. all5 ikatan BPA dengan ERs (ERa dan ERß) lebih kuat dibanding dengan ERR-Y. Lebih lengkapnya, BPA berikatan 3 kali lebih kuat dengan ER $\beta$ dibandingkan dengan ERa. BPA yang masuk ke dalam tubuh, dalam hal ini berperan sebagai $E_{2}$, berikatan dengan ER $\beta$ kemudian menekan ekspresi GLUT4 sehingga insulin tidak dapat digunakan oleh jaringan. Disisi lain, aktivasi ER $\beta$ juga menginduksi sel $\beta$ pankreas untuk memproduksi insulin lebih banyak. Insulin akan banyak menumpuk di pembuluh darah dan akan menyebabkan hiperinsulimia. Pada pembuluh darah, insulin menginduksi terjadinya vasodilatasi yang mana diduga untuk meningkatkan aliran darah sehingga nutrisi, dalam hal ini glukosa, dapat banyak tersampaikan ke dalam otot. ${ }^{16}$

Keadaan hiperinsulimia pada tikus percobaan didukung dengan kenaikan kadar glukosa dalam darah. Pada data tambahan, berupa kadar glukosa darah yang diperiksa pada minggu pertama hingga minggu keenam terjadi peningkatan pada kelompok P. Uji korelasi yang digunakan pada kadar glukosa dan kadar insulin kelompok $\mathrm{P}$ juga menunjukkan bahwa kadar glukosa dan kadar insulin kelompok $\mathrm{P}$ memiliki hubungan yang positif serta dengan tingkat korelasi sempurna. Hal ini menunjukkan bahwa semakin besar kadar glukosa maka semakin besar pula kadar insulin dalam serum darah tikus wistar jantan yang telah dipapar BPA. Dari kedua ini dapat disimpulkan bahwa kemungkinan DMT2 yang terjadi akibat induksi BPA disebabkan oleh intoleransi insulin, dengan ciri-ciri terjadi hiperinsulimia dan hiperglikemi disaat yang bersamaan.

Berdasarkan hasil penelitian yang telah dilakukan, dapat disimpulkan bahwa bahwa kadar $20 \mathrm{mg} / \mathrm{kgBB}$ BPA dapat meningkatkan kadar insulin dalam serum darah sebanyak $1,38 \mathrm{mlU} / \mathrm{L}$. Beberapa saran yang dapat diberikan penulis adalah perlu dilakukan peneltian lain dengan dosis yang lebih besar dan tentang waktu pemberian BPA yang lebih lama dari yang digunakan di penelitian serta perubahan yang terjadi pada parameter lain atau secara histopatologi pada organ tikus yang telah diinduksi oleh BPA.

\section{DAFTAR PUSTAKA}

1. Mileva G., Baker S, Konkle A dan Bielajew C. Bisphenol-A: Epigenetic Reprogramming and Effects on Reproduction and Behaviour. International Journal of Environmental Research and Public Health. 2014; 11 (7): 7537-61.

2. Peretz J., Vrooman L, Ricke WA, Hunt PA, Ehrlich S, Hauser R, Padmanabhan V, Taylor HS, Swan SH, VandeVoort CA, dan Flaws JA. Bisphenol $A$ and Reproductive Health: Update of Experimental and Human Evidence, 2007-2013. Environ Health Perspect. 2014; 122(8): 775-86.

3. Hoekstra EJ dan Simoneau C. Release of bisphenol A from polycarbonate: a review. Crit Rev Food Sci Nutr. 2013; 53(4):386-402.

4. Ganong WF. BukU Ajar Fisiologi Kedokteran. Edisi 25. Jakarta: EGC. 2015

5. Guyton AC dan Hall JE. Buku Ajar Fisiologi Kedokteran, Edisi 14. Jakarta: EGC. 2015 
6. Shanle EK dan XU W. Endocrine disrupting chemicals targeting estrogen receptor signaling: Identification andmechanisms of action. Chem. Res. Toxicol. 201 1; 24: 6-19.

7. Perdana WY dan Jacobus DJ. Bisphenol A(BPA) adalah Endocrine Disrupture Chemicals (EDC) yang Berperan sebagai Agen Diabetogenik. CDK-244/ 2016; 43(9).

8. Nadal A., Alonso-Magdalena P, Soriano S, Ripoll C, Fuentes E, Quesada I dan Ropero $A B$. Role of estrogen receptors alpha, beta and GPER1/GPR30 in pancreatic beta-cells. Front Biosci (Landmark Ed). 201 1; 16: 251-60.

9. Zahreni H. Peningkatan Jumlah Sel Punca Mesenkimal Ligamen Periodontal Penghasil HSP-60 dan TGF-beta Berperan pada Mobilitas Gigi Tikus SD yang Mengalami Distres Kerja Kronis. Universitas Airlangga. 2015

10. Yan YX., Xiao HB, Wang SS, Zhao J, He $Y$, Wang $W$ dan Dong J. Investigation of the Relationship Between Chronic Stress and Insulin Resistance in a Chinese Population. J Epidemiol. 2016; 26(7): 35560.

11. Yang J., Dungrawala $H$, Hua $H$, Manukyan A, Abraham L, Lane W, Mead H, Wright J dan Schneider BL. Cell size and growth rate are major determinants of replicative lifespan. Cell Cycle. 2011; 10(1), 144-55.

12. Alonso-Magdalena P., Ropero AB., Soriano S, Quesada I, dan Nadal A. Bisphenol-A: A new diabetogenic factor?. Hormones. 2010; 9(2): 118-26.

13. Root-Bernstein R., Podufaly A dan Dillon PF. Estradiol Binds to Insulin and Insulin Receptor Decreasing Insulin Binding in vitro. Int Neurourol J. 2018; 22(3): 161-168.

14. Carrasco-Ruiz MLÁ, Hernández-Aragón LG, Chávez-Ríos JR, Rodríguez-Antolín J, Pacheco P Martínez-Gómez M, CuevasRomero E dan Castelán F. High Estradiol Differentially Affects the Expression of the Glucose Transporter Type 4 in Pelvic Floor Muscles of Rats. Int Neurourol J. 2018; 22(3):161-168.

15. Matsushima A., Liu $\mathrm{X}$, Okada $\mathrm{H}$, Shimohigashi $M$ dan Simohigashi $Y$. Bisphenol AF Is a Full Agonist for the Estrogen Receptor ERa but a JieHighly Specific Antagonist for ERß. Environmental Health Perspective. 2010; 118(9): 1267-72.

16. Richards OC., Raines SM, dan Attie AD. The Role of Blood Vessels, Endothelial Cells, and Vascular Pericytes in Insulin Secretion and Peripheral Insulin Action. Endocrine Reviews, 2010; 31 (3), 343-63. 